\title{
Thrombophilic mutations and risk of retinal vein occlusion
}

\author{
Mutações trombofílicas e risco de oclusão venosa retiniana
}

\author{
Ana Luiza Biancardi ${ }^{1}$ \\ Telma Gadelha ${ }^{2}$ \\ Wander Inturias Sergillo Borges ${ }^{3}$ \\ Haroldo Vieira de Moraes Jr. ${ }^{4}$ \\ Nelson Spector ${ }^{5}$
}

\begin{tabular}{l} 
ABSTRACT \\
\hline Purpose: The association of retinal vein occlusion and hereditary throm- \\
bophilia abnormalities is not established, with controversial results in the \\
literature. This study investigates the association between retinal vein \\
occlusion and three thrombophilic mutations: factor V 1691A (factor V \\
Leiden), prothrombin 20210A (PT 20210A) and homozygous methy- \\
lenetetrahydrofolate reductase 677T (MTHFR 677TT). Methods: 55 \\
consecutive retinal vein occlusion patients and 55 controls matched by \\
age, gender and race, were tested for the presence of the following \\
mutations: factor V Leiden, PT 20210A and MTHFR 677TT. The fre- \\
quencies of the three mutations in cases and controls were compared. \\
Results: Factor V Leiden was found in 3.6\% of patients and in 0\% of \\
controls; PT 20210A was found in 1.8\% of patients and 3.6\% of controls, \\
(matched-pair odds ratio, 0.5; 95\% confidence interval, 0.04 to 5.51); \\
MTHFR 677TT was found in 9\% of patients and 9\% of controls (matched- \\
pair odds ratio, 1; 95\% confidence interval, 0.92 to 3.45). Arterial \\
hypertension was more frequent in patients than controls (matched-pair \\
odds ratio, 3.4; 95\% confidence interval, 1.25 to 9.21). Conclusions: This \\
study suggests that thrombophilic mutations are not risk factors for RVO. \\
Routine investigation of hereditary thrombophilia in these patients is \\
not justified.
\end{tabular}

Keywords: Retinal vein occlusion; Risk factors; Thrombophilia; Factor V; Prothrombin; Methylenetetrahydrofolate reductase (NADPH2)

\section{INTRODUCTION}

Retinal vein occlusion (RVO) is a major cause of visual impairment and blindness, especially in the elderly ${ }^{(1-2)}$. Coagulation abnormalities, changes in blood vessel walls and systemic conditions such as hypertension, atherosclerosis and diabetes mellitus seem to be associated with $\mathrm{RVO}^{(1-2)}$. However, in many cases none of these factors are present, and the question of hidden risk factors is raised.

Three highly prevalent mutations have been described in association with thrombosis: factor V Leiden $(\mathrm{FV} 1691 \mathrm{~A})^{(3)}$, the prothrombin variant (PT 20210A) $)^{(4)}$ and homozygosity for the thermolabile methylenetetrahydrofolate reductase (MTHFR 677TT) ${ }^{(5)}$. These mutations increase the risk of thrombosis through different mechanisms. It is well established that factor V Leiden and PT 20210A are associated with an increased risk of venous thrombosis ${ }^{(6-7)}$. The MTHFR 677TT has also been studied, with controversial results ${ }^{(8-11)}$. The risk associated with these mutations varies with the topography of venous thrombosis ${ }^{(12-14)}$. In the case of RVO, the 
role of these mutations is still unclear. The purpose of this study was to evaluate if these mutations are risk factors for retinal vein occlusion.

\section{METHODS}

\section{Patients}

A 1:1 matched case-control study was performed, including all patients referred to the hemostasis laboratory between October 1999 and January 2005 with RVO. A total of 55 patients were included.

\section{Controls}

A pool of controls was established, consisting of individuals brought in by the patients, not genetically related, as well as other patients from the hospital with no history of thrombosis (formally enquired). Each case was matched to a control according to age ( \pm 3 years), gender, and racial background (defined as Caucasian or Afro-Brazilian based on the familial background and phenotypic characteristics as determined by the interviewers).

Therefore, 55 case-control pairs were available for the analysis.

\section{Laboratory tests}

After signing an informed consent, patients and controls had a $10 \mathrm{~mL}$ blood sample collected in EDTA for DNA analysis. Genomic DNA was isolated from peripheral blood leukocytes by a standard procedure. Detection of factor V Leiden was carried out by the polymerase chain reaction (PCR) of a fragment of exon 10 of the factor $\mathrm{V}$ gene, digested by $\mathrm{MnII}^{(3)}$. For the identification of PT 20210A, DNA was amplified and digested by HindIII ${ }^{(4)}$. The MTHFR C677T was detected by HinfI cleavage of a PCR-amplified product ${ }^{(5)}$.

\section{Risk factors}

Hypertension, diabetes mellitus, and the three mutations (factor V Leiden, PT 20210A and MTHFR 677TT) were assessed as potential risk factors for retinal thrombosis. Hypertension was defined by either the use of antihypertensive drugs or by a diastolic blood pressure $>90 \mathrm{mmHg}$ or a systolic blood pressure $>140 \mathrm{mmHg}$ on two consecutive measurements in different days. Diabetes mellitus was defined on the basis of whether the subject was using insulin or glucoselowering drugs or on criteria of the American Diabetes Association, namely a fasting plasma glucose $\geq 126 \mathrm{mg} / \mathrm{dL}$ ( 7.0 $\mathrm{mmol} / \mathrm{L})$ or 2 -h postload glucose $\geq 200 \mathrm{mg} / \mathrm{dL}(11.1 \mathrm{mmol} / \mathrm{L})$ during an oral glucose tolerance test.

\section{Statistical analysis}

The matched-pair odds ratios and the $95 \%$ confidence intervals (CI) were calculated from the number of discordant pairs. The tests were performed using Epi-Info (Centers for Disease Control and Prevention, USA) and Win Episcope 2.0.

\section{RESULTS}

The series included 32 women (58\%) and 23 men (42\%), with a median age of 61.5 years (range $17-83$ years). Thirtyseven $(67 \%)$ patients were Caucasians and $18(33 \%)$ were African-Brazilians. Thirty-one patients (56\%) and nineteen controls $(35 \%)$ had hypertension (matched-pair odds ratio, $3.4 ; 95 \%$ confidence interval, 1.25 to 9.21 ). The frequency of diabetes mellitus was the same $(9 \%)$ in the two groups.

The distribution of the three genotypes in patients and controls is shown in table 1 . A hereditary thrombophilia was found in 7 patients (13\%): factor V Leiden (in heterozygous) in 2 patients, PT 20210A (in heterozygous) in 1 patient and MTHFR 677TT (in homozygous) in 5 patients (one patient had both factor V Leiden and MTHFR 677TT). One patient with FV Leiden also had deep venous thrombosis of lower limbs. None of the patients, including this one, was using anticoagulant treatment at the moment of the RVO. A hereditary thrombophilia was also present in 7 controls (13\%): PT 20210A in 2 and MTHFR 677TT in 5. Only factor V Leiden was more frequent in patients than in controls $(3.6 \%$ versus $0 \%$ ). The risk of RVO was not significantly higher in individuals presenting either one of the three mutations.

Twenty-three patients were younger than 60 years. The prevalence of mutations in this younger group was not higher compared to older subjects (one patient had factor V Leiden and two presented MTHFR 677TT).

There were 3 patients (9\%) with mutations among the 33 patients with central retinal vein occlusion, and $4(18 \%)$ among the 22 patients with occlusion in a branch of the retinal vein, but these prevalences were not significantly different from the control group.

\section{DISCUSSION}

Retinal vein occlusion is a common disorder in elderly patients. The Blue Mountains Eye Study found a prevalence of retinal venous occlusive disease of $0.7 \%$ in individuals younger than 60 years, $1.2 \%$ in individuals aged 60 to 69 years, and $4.6 \%$ in individuals older than 80 years $^{(15)}$. The identification of risk factors would be an important step towards the prevention of this potentially ominous disorder.

The frequency of thrombophilic mutations in patients presenting RVO in previous studies range from $0 \%$ to $17 \%$ for the factor $\mathrm{V}$ Leiden ${ }^{(16-20)}$, from $0 \%$ to $10 \%$ for PT $20210 \mathrm{~A}^{(16,19,21-24)}$ and from $3 \%$ to $19 \%$ for MTHFR $677 \mathrm{TT}^{(25-30)}$. These differences may be related to the racial background, selection of the control group, and study design. In the present study, the frequencies of FV1691A, PT20210A and MTHFR were 4\%, 2\% and 9\% respectively.

Studies investigating the presence of activated protein $\mathrm{C}$ resistance or factor $\mathrm{V}$ Leiden have suggested their potential role in $\mathrm{RVO}^{(16,25,29)}$. Recently, a study ${ }^{(31)}$ also suggested that the presence of factor $\mathrm{V}$ Leiden increases the risk of neo- 


\begin{tabular}{|c|c|c|c|}
\hline & $\begin{array}{c}\text { Patients (55) } \\
\text { n (\%) }\end{array}$ & $\begin{array}{c}\text { Controls (55) } \\
n(\%)\end{array}$ & Odds ratio $(\mathrm{Cl} 95 \%)$ \\
\hline Factor V Leiden ${ }^{\mathrm{a}}$ & $2(3.6)$ & $0(0)$ & NQ \\
\hline MTHFR $677 T^{c}$ & $5(9.0)$ & $5(9.0)$ & $1.0(0.29-3.45)$ \\
\hline
\end{tabular}

vascular complications in patients presenting central RVO. However, despite being the thrombophilic abnormality most frequently associated with RVO, most studies have failed to show a role for this mutation in $\mathrm{RVO}^{(17-19,22,26,32)}$. In the present study, factor $\mathrm{V}$ Leiden was the only mutation with a higher frequency in patients than in controls $(3.6 \%$ versus $0 \%)$. In a previous report, a prevalence of $1 \%$ for factor $\mathrm{V}$ Leiden in a normal cohort of Brazilians was observed ${ }^{(12)}$. Therefore, the increased prevalence in patients with RVO cannot be ruled out, and this matter requires further study.

A higher prevalence of the prothrombin variant PT20210A in patients with central retinal vein occlusion was also reported ${ }^{(23)}$, but has not been confirmed in most stu$\operatorname{dies}^{(26,28-30,33)}$. In the present study, this mutation was not more frequent among patients.

Higher levels of plasmatic homocysteine in patients with RVO have also been reported ${ }^{(34-35)}$ and two case-control studies identified MTHFR 677TT as a potential risk factor for $\mathrm{RVO}^{(32,36)}$. Nevertheless, most studies did not confirm the role of this mutation in $\mathrm{RVO}^{(26,28-30)}$. In the present study, the same frequency of MTHFR 677TT was found in cases and controls.

Even when analyzing separately in central retinal vein occlusion (CRVO) and branch retinal vein occlusion (BRVO), the mutations did not represent a risk for RVO. Occlusion of the central retinal vein occurs at a variable distance posterior to the lamina cribosa, where the central retinal vein shares a common adventitial sheath with the central retinal artery ${ }^{(37-39)}$. On the other hand, BRVO is associated with arteriosclerotic changes in the retinal arterioles and the resultant thickening appears to cause compression of adjacent veins, a process that may be aggravated because the two vessels are confined within a common adventitial sheath ${ }^{(40)}$.

In this study, it is also noteworthy that the mutations did not represent a risk for RVO in patients younger than 60 years.

Some limitations of this study must be mentioned. The clinical status of patients with arterial hypertension and diabetes mellitus was not available in all cases. In some cases, the angiographic exam was not performed in the acute phase of the OVR. Finally, the definition of race in the Brazilian population is always controversial. Unlike any other country in the Americas, the Portuguese colonization in Brazil was marked by intense racial mixing of European, African and Indian groups, with gradual loss of traditional phenotypic and genotypic boundaries. In the present study, individual were classified as Caucasians or Afro-Brazilians by a simple and quite subjective examination by the interviewers. However, any interpretation of race in the Brazilian context must be met with substantial reservation.

\section{CONCLUSION}

In summary, our results show no indication that the mutations PT 20210A or MTHFR 677TT have a role in predisposing patients to RVO. The prevalence of Factor $\mathrm{V}$ Leiden was also low in the present study, but its role in RVO demands further study. Routine screening for these mutations in patients with RVO is not indicated.

\section{RESUMO}

Objetivos: A associação entre oclusão venosa retiniana e trombofilias hereditárias não está estabelecida, com resultados controversos na literatura. O presente estudo investiga a associação entre a oclusão venosa retiniana e três mutações trombofílicas: fator V 1691A (fator V Leiden), protrombina 20210A (PT 20210A) e mutação C677T do gene da metilenotetra-hidro-folato redutase (MTHFR 677TT). Métodos: Cinquenta e cinco pacientes portadores de oclusão venosa retiniana e 55 controles pareados por idade, sexo e raça foram testados para a presença das seguintes mutações: fator $\mathrm{V}$ Leiden, PT 20210A e MTHFR 677TT. As freqüências das três mutações em casos e controles foram comparadas. Resultados: Fator V Leiden foi encontrado em 3,6\% dos pacientes e em $0 \%$ dos controles; PT 20210A foi encontrada em $1.8 \%$ dos pacientes e em 3,6\% dos controles, (odds ratio, 0,$5 ; 95 \%$ IC, 0,04 to 5,51); MTHFR 677TT foi encontrada em 9\% dos pacientes e em 9\% dos controles (odds ratio, 1; 95\% IC, 0,92 to 3,45$)$. Hipertensão arterial foi encontrada mais freqüentemente em pacientes do que em controles (odds ratio, 3,4; 95\% IC, 1,25 to 9,21). Conclusões: O presente estudo sugere que mutações trombofílicas não são fatores de risco para oclusão venosa retiniana. A investigação rotineira para trombofilias hereditárias neste grupo de pacientes não é indicada.

Descritores: Oclusão da veia retiniana; Fatores de risco; Trombofilia; Fator V; Protrombina; Metilenotetraidrofolato redutase (NADPH2) 


\section{REFERENCES}

1. Risk factors for central retinal vein occlusion. The Eye Disease Case-Control Study Group. Arch Ophthalmol. 1996;114(5):545-54

2. Risk factors for branch retinal vein occlusion. The Eye Disease Case-Control Study Group. Am J Ophthalmol. 1993;116(3):286-96.

3. Bertina RM, Koeleman BP, Koster T, Rosendaal FR, Dirven RJ, de Ronde $\mathrm{H}$, et al. Mutation in blood coagulation factor $\mathrm{V}$ associated with resistance to activated protein C. Nature. 1994;369(6475):64-7. Comment in: Nature. 1994;369(6475):14-5.

4. Poort SR, Rosendaal FR, Reitsma PH, Bertina RM. A common genetic variation in the 3 '-untranslated region of the prothrombin gene is associated with elevated plasma prothrombin levels and an increase in venous thrombosis. Blood. 1996;88(10):3698-703.

5. Frosst P, Blom HJ, Milos R, Goyette P, Sheppard CA, Matthews RG, et al. A candidate genetic risk factor for vascular disease: a common mutation in methylenetetrahydrofolate reductase. Nat Genet. 1995;10(1):111-3.

6. Ridker PM, Hennekens CH, Lindpaintner K, Stampfer MJ, Eisenberg PR, Miletich JP. Mutation in the gene coding for coagulation factor $\mathrm{V}$ and the risk of myocardial infarction, stroke and venous thrombosis in apparently healthy men. N Engl J Med. 1995;332(14):912-7. Comment in: N Engl J Med. 1995;333(13):880-1. N Engl J Med. 1995;333(13):881.

7. Lindmarker P, Schulman S, Sten-Linder M, Wiman B, Egberg N, Johnsson $\mathrm{H}$. The risk of recurrent venous thromboembolism in carriers and non-carriers of the G1691A allele in the coagulation factor V gene and the G20210A allele in the prothrombin gene. DURAC Trial Study Group. Duration of Anticoagulation. Thromb Haemost. 1999;81(5):684-9.

8. Arruda VR, von Zuben PM, Chiaparini LC, Annichino-Bizzacchi JM, Costa FF. The mutation Ala677 $\rightarrow$ Val in the methylene tetrahydrofolate reductase gene: a risk factor for arterial disease and venous thrombosis. Thromb Haemost. 1997;77(5):818-21.

9. den Heijer M, Rosendaal FR, Blom HJ, Gerrits WB, Bos GM. Hyperhomocysteinemia and venous thrombosis: a meta-analysis. Thromb Haemost. 1998; 80(6):874-7.

10. Zheng YZ, Tong J, Do XP, Pu XQ, Zhou BT. Prevalence of methylenetetrahydrofolate reductase $\mathrm{C} 677 \mathrm{~T}$ and its association with arterial and venous thrombosis in the Chinese population. Br J Haematol. 2000;109(4):870-4.

11. Kluijtmans LA, den Heijer M, Reitsma PH, Heil SG, Blom HJ, Rosendaal FR. Thermolabile methylenetetrahydrofolate reductase and factor $\mathrm{V}$ Leiden in the risk of deep venous thrombosis. Thromb Haemost. 1998;79(2):254-8.

12. Martinelli I, Sacchi E, Landi G, Taioli E, Duca F, Mannucci PM. High risk of cerebral Vein thrombosis in carriers of a prothrombin-gene mutation and in users of oral contraceptives. Engl J Med. 1998;338(25):1793-7. Comment in: N Engl J Med. 1998;338(25):1840-1.

13. Gadelha T, André C, Jucá AA, Nucci M. Prothrombin 20210A and oral contraceptive use as risk factors for cerebral venous thrombosis. Cerebrovasc Dis. 2005;19(1):49-52

14. Primignani M, Martinelli I, Bucciarelli P, Battaglioli T, Reati R, Fabris F, et al. Risk Factors for thrombophilia in extrahepatic portal vein obstruction. Hepatology. 2005;41(3):603-8

15. Mitchell P, Smith W, Chang A. Prevalence and associations of retinal vein occlusion in Australia. The Blue Mountains Eye Study. Arch Ophthalmol. 1996;114(10):1243-7.

16. Aras S, Yilmaz G, Alpas I, Baltaci V, Tayanç E, Aydin P. Retinal vein occlusion and factor V Leiden and prothrombin $20210 \mathrm{G}$ :A mutation. Eur J Ophthalmol. 2001;11(4):351-5.

17. Kuhli C, Hattenbach LO, Scharrer I, Koch F, Ohrloff C. High prevalence of resistance to APC in young patients with retinal vein occlusion. Graefe's Arch Clin Exp Ophthalmol. 2002;240(3):163-8.

18. Johnson TM, El-Defrawy S, Hodge WG, Leonard BC, Kertes PJ, Taylor $\mathrm{SAM}$, et al. Prevalence of factor $\mathrm{V}$ Leiden and activated protein $\mathrm{C}$ resistance in central retinal vein occlusion. Retina. 2001;21(2):161-6.

19. Weger M, Renner W, Steinbrugger I, Cichocki L, Temmel W, Stanger O, et al. Role of thrombophilic gene polymorphisms in branch retinal vein occlusion. Ophthalmology. 2005;112(11):1910-5.
20. Scott JA, Arnold JJ, Currie JM, Broadfoot C, Davidson M, Kelly KF, et al. No excess of factor $\mathrm{V}: \mathrm{Q} 506$ genotype but high prevalence of anticardiolipin antibodies without antiendothelial cell antibodies in retinal vein occlusion in young patients. Ophthalmologica. 2001;215(3):217-21.

21. Arsène $\mathrm{S}$, Delahousse $\mathrm{B}$, Regina $\mathrm{S}$, Le Lez ML, Pisella PJ, Gruel Y. Increased prevalence of factor $\mathrm{V}$ Leiden in patients with retinal vein occlusion and under 60 years of age. Thromb Haemost. 2005;94(1):101-6.

22. Backhouse O, Parapia L, Mahomed I, Lee D. Familial thrombophilia and retinal vein occlusion. Eye. 2000;14(Pt 1):13-7.

23. Incorvaia C, Parmeggiani F, Costagliola C, Lamberti G, Ferraresi P, Bernardi $\mathrm{F}$, et al. The heterozygous 20210A genotype prevalence in patients affected by central and branch retinal vein occlusion: a pilot study. Graefe's Arch Clin Exp Ophthalmol. 2001;239(4):251-6.

24. Boyd S, Owens D, Gin T, Bunce K, Sherafat H, Perry D, et al. Plasma homocysteine, methylene tetrahydrofolate reductase $\mathrm{C} 677 \mathrm{~T}$ and factor G20210A polymorphisms, factor VIII, and VWF in central retinal vein occlusion. Br J Ophthalmol. 2001;85(11):1313-5.

25. Löewenstein A, Goldstein M, Winder A, Lazar M, Eldor A. Retinal vein occlusion associated with methylenetetrahydrofolate reductase mutation. Ophtalmology 2000;106(9):1817-20. Erratum in: Ophthalmology. 2000;107(2):228.

26. Marcucci R, Bertini L, Giusti B, Brunelli T, Fedi S, Cellai AP, et al Thrombophilic risk factors in patients with central retinal vein occlusion. Thromb Haemost. 2001;86(3):722-6.

27. Di Crecchio L, Parodi MB, Sanguinetti G, Iacono P, Ravalico G. Hyperhomocysteinemia and the methylenetetrahydrofolate reductase $677 \mathrm{C}-\mathrm{T}$ mutation in patients under 50 years of age affected by central retinal vein occlusion. Ophthalmology. 2004;111(5):940-5.

28. Weger M, Stanger O, Deutschmann H, Temmel W, Renner W, Schmut O, et al. Hyperhomocyst(e)inemia, but not methylenetetrahydrofolate reductase C677T mutation, as risk factor in branch retinal vein occlusion. Ophthalmology. 2002;109(6):1105-9. Comment in: Ophthalmology. 2003;110(10):2069; author reply 2069

29. Larsson J, Olafsdottir E, Bauer B. Activated protein C resistance in young adults with central retinal vein occlusion. Br J Ophthalmol. 1996;80(3):200-2.

30. Weger M, Stanger O, Deutschmann H, Temmel W, Renner W, Schmut O, et al. Hyperhomocyst(e)inemia and MTHFR C677T genotypes in patients with central retinal vein occlusion. Graefe's Arch Clin Exp Ophthalmol. 2002;240(4):286-90.

31. Hvarfner C, Hillarp A, Larsson J. Influence of factor V Leiden on the development of neovascularization secondary to central retinal venous occlusion. Br J Ophthalmol. 2003;87(3):305-6.

32. Salomon O, Moisseiev J, Rosenberg N, Vidne O, Yassur I, Zivelin A, et al. Analysis of genetic polymorphisms related to thrombosis and other risk factors in patients with retinal vein occlusion. Blood Coagul Fibrinolysis. 1998;9(7):617-22.

33. Cruciani F, Moramarco A, Curto T, Labate A, Recupero V, Conti L, et al. MTHFR C677T mutation, factor II G20210A mutation and factor V Leiden as risks factor for youth retinal vein occlusion. Clin Ter. 2003;154(5):299-303.

34. Cahill M, Karabatzaki M, Meleady R, Refsum H, Ueland P, Shields D, et al. Raised plasma homocysteine as a risk factor for retinal vascular occlusive disease. Br J Ophthalmol. 2000;84(2):154-7.

35. Lahey JM, Tunc M, Kearney J, Modlinski B, Koo H, Johnson RN, et al. Laboratory evaluation of hypercoagulable states in patients with central retinal vein occlusion who are less than 56 years of age. Ophthalmology. 2002;109 (1):126-31.

36. Terrazzi P, Di Micco P, Quaglia I, Rossi LS, Bellatorre AG, Gaspari G, et al. Homocysteine, MTHFR C677T gene polymorphism, folic acid and vitamin B 12 in patients with retinal vein occlusion. Thromb J. 2005;3:13-8.

37. Larsson J, Hultberg B, Hillarp A. Hyperhomocysteinemia and the MTHFR C677T mutation in central retinal vein occlusion. Acta Ophthalmol Scand. 2000;78(3)340-3.

38. Hayreh SS. Prevalent misconceptions about acute retinal vascular occlusive disorders. Prog Retin Eye Res. 2005;24(4):493-519.

39. Williamson TH. Central retinal vein occlusion: what's the story? Br J Ophthalmol. 1997;81(8):698-704.

40. Christoffersen NL, Larsen M. Pathophysiology and hemodynamics of branch retinal vein occlusion. Ophthalmology. 1999;106(11):2054-62. 